\title{
Recurrent respiratory infections in the follow-up of the extremely low birth weight infant
}

\author{
Oliviero Sacco, Michela Silvestri, Giovanni A Rossi \\ From XXI Congress of the Italian Society of Neonatology \\ Palermo, Italy. 24-26 September 2015
}

Most of the extremely low birth weight (ELBW) infants, those with a birth weight $<1,000 \mathrm{~g}$, are also the youngest of premature newborns, usually with a $<27$ weeks' gestational age (wGA). ELBW survival has improved with advancement of neonatal technologies, but survivors may face early and life-long morbidities that includeinfectious respiratory disorders[1]. This increased predisposition is related to a variety of immunological, structural and iatrogenic factors. At the time of term birth, the innate immune response has not fully matured and the adaptive immune system must still develop specificity and memory, completed only in the early childhood [2]. The immaturity of the innate immune systemis more pronounced in preterm infants. The classical, alternative and lectin complement pathways are all reduced in their pathogen-killing abilities and the production and release of soluble antimicrobial proteins and peptidesby leukocytes are deficient. Preterm infants have reduced pool of neutrophils and monocytes and their precursors, compared to term-neonates, and have deficient $\mathrm{T}$ cell function with greater proportion of naive $\mathrm{T}$ cells and a low subpopulation of memory $\mathrm{T}$ cells. A reduction in lymphocyte subpopulations is still detectable at 8 years of age. There is also a limited production of immunoglobulin (Ig) by the fetus and antigen-specific IgGs are transferred across the placenta from the maternal circulation in large amounts after $32 \mathrm{wGA}$. The lung structures are also structurally and functionally immature in the ELBW. An early complication of extreme prematurity is respiratory distress syndrome caused by surfactant deficiency, with collapse of the alveolar structures, atelectasis edema and decreased lung capacity. Supplemental oxygen and ventilatorysupport may leadto complication, such as air leak syndrome and chronic lung disease of prematurity

\footnotetext{
* Correspondence: giovannirossi@ospedale-gaslini.ge.it

Department of Pediatrics, Pulmonary Unit, IstitutoGianninaGaslini, Genoa, Italy
}

and increase the risk of persistent damage to the fragile, immature pulmonary structures [3]. Infections are a major contribution to the morbidity and mortality of ELBW infants at any time of the clinical course [4]. The incidence of early-onset infections, due to bacteria from the maternal genital tract but also to nosocomial environmental bacteria and fungi and to airborne viruses, increases in the U.S.A. from $<1 / 1000$ live births to $8 / 1000$ in ELBW births. ELBW infants are also at high risk of vaccine-preventable diseases, such as pertussis and Haemophilus influenzae and Corynebacterium diphtheriae infections: according to the international recommendations, they should receive full doses of the conjugate vaccines at the appropriate chronological age [5].

\section{Published: 24 September 2015}

References

. Stoll BJ, Hansen NI, Bell EF, Shankaran S, Laptook AR, Walsh MC, Hale EC, Newman NS, Schibler K, Carlo WA, Kennedy KA, Poindexter BB, Finer NN, Ehrenkranz RA, Duara S, Sánchez PJ, O'Shea TM, Goldberg RN, Van Meurs KP, Faix RG, Phelps DL, Frantz ID 3rd, Watterberg KL, Saha S, Das A, Higgins RD, Eunice Kennedy Shriver National Institute of Child Health and Human Development Neonatal Research Network: Neonatal outcomes of extremely preterminfants from the NICHD Neonatal Research Network. Pediatrics 2010, 126:443e6.

2. Hack M, Flannery DJ, Schluchter M, Cartar L, Borawski E, Klein N: Outcomes in young adulthood for very-low-birth-weight infants. N Engl J Med 2002, 346:149-157.

3. Baraldi E, Filippone M: Chronic lung disease after premature birth. N Engl J Med 2007, 357:1946-1955.

4. Hodgman JE, Barton L, Pavlova Z, Fassett MJ: Infection as a cause of death in the extremely-low-birth-weight infant. J Matern Fetal Neonatal Med 2003, 14:313-317.

5. Esposito S, Fumagalli M, Principi N: Immunogenicity, safety and tolerability of vaccinations in premature infants. Expert Rev Vaccines 2012, 11:1199-1209.

doi:10.1186/1824-7288-41-S1-A36

Cite this article as: Sacco et al:: Recurrent respiratory infections in the follow-up of the extremely low birth weight infant. Italian Journal of Pediatrics 2015 41(Suppl 1):A36.
Pellow-up of the extremely low b 